Gut, 1982, 23, 1019-1023

\title{
Adrenergic influence on concentrating function in the feline gall bladder
}

\author{
S BJÖRCK, R JANSSON, and J SVANVIK* \\ From the Department of Surgery III, University of Göteborg, Sweden
}

SUMMARY The influence of adrenergic drugs and electrical stimulation of the splanchnic nerves on concentrating function and motility in the feline gall bladder and on hepatic bile secretion have been studied in vivo. It was found that electrical stimulation of the splanchnic nerves and adrenergic $\alpha$-receptor stimulation increase the rate of net water absorption from the gall bladder lumen. Adrenergic $\beta$-receptor stimulation relaxed the gall bladder but did not influence the concentrating function. A direct effect on the mucosal cells and/or a ganglionic inhibition of intramural VIP-releasing neurons is suggested as a possible mechanism for the $\alpha$-adrenergic increase of the net water absorption rate. The results are discussed in relation to the adrenergic influence on water absorption in the small intestine. As a functional consequence of an increase in the concentrating activity of the gall bladder in situations of high adrenergic activity a more rapid accummulation of organic contents in its lumen is suggested.

In 1932 Johnston and coworkers found that the rate of fluid absorption in the gall bladder of dogs had a diurnal variation. ${ }^{1}$ At night, at sleep, the absorption rate was found to be one-third of that during day time. Diamond later suggested that the absorptive function of the gall bladder was controlled by nerves and hormones. ${ }^{2}$

Recently the effect of gastrointestinal peptides on the concentrating function in the gall bladder have been investigated in vivo. Secretin was found to inhibit the net water absorption in the gall bladder ${ }^{3}$ and VIP reversed the net flux of fluid from an absorption into a secretion. ${ }^{4}$ There are in the literature few studies on the effects of autonomic nerves on the concentrating function of the gall bladder. Westphal and coworkers in 1931 found that electrical vagus stimulation increased the net water absorption in the gall bladder. ${ }^{5}$ The results, however, were not consistent, and in a few experiments a reduced water transport was noted. It is shown that acetylcholine in vitro causes a small stimulation of water transport in fish gall bladder while adrenaline causes a slight inhibition. ${ }^{2}$ Noradrenaline in the everted human gall bladder is found to increase the net water absorption. ${ }^{6}$

* Address for reprint requests: Dr Joar Svanvik. Department of Surgery III, University of Göteborg, Sahlgrenska sjukhuset, S-413 45 Göteborg. Sweden. Received for publication 15 February 1982
Stimulation of $\alpha$-adrenergic receptors in the gut seems to enhance sodium, chloride, and water absorption. ${ }^{78}$ Further, Brunsson and coworkers ${ }^{9}$ have found that electrical stimulation of the splanchnic nerves increases the net water absorption from the small intestine. So far the effect of $\alpha$ - and $\beta$-adrenergic agents and electrical stimulation of the splanchnic nerves on the rate of net water transport in the gall bladder has not been studied in vivo.

Histological studies have demonstrated noradrenergic nerve fibres in the human gall bladder ${ }^{10}$ and in many animal models the tissue concentration of noradrenaline in the extrahepatic biliary tract seems to exceed that in the small intestine. ${ }^{11}$ Recently, gastrointestinal peptides have been demonstrated in the splanchnic nerves and a fraction of these fibres might be peptidergic. ${ }^{12}$ The present study was undertaken to study, with recently described perfusion techniques, the adrenergic influence on the concentrating function of the gall bladder. A preliminary report on this paper has been published. ${ }^{13}$

\section{Methods}

EXPERIMENTAL PROCEDURES AND MEASUREMENTS OF NET WATER TRANSPORT

Experiments were performed on 36 cats, anaesthetised with chloralose $(50-70 \mathrm{mg} / \mathrm{kg}$ body 
weight) after induction with ether. The animals had been deprived of food for 24 hours. The experimental approach was similar to that described in an earlier paper. ${ }^{14}$ To summarise, the method includes a continuous perfusion of the cystic duct ligated gall bladder in situ, with an electrolyte solution, by a roller pump at the rate of $0.1 \mathrm{ml} / \mathrm{min}$. Two plastic cannulas were inserted through the fundus of the gall bladder, one with its end in the collum and one with its end in the fundus. The gall bladder was rinsed with bodywarm perfusate until the effluent was clear. The cystic duct was carefully dissected and ligated, taking care not to damage the cystic artery, lymph vessels, and nerves. The pylorus was ligated. Body temperature was maintained at $38^{\circ} \mathrm{C}$ by means of a thermostatically regulated heating pad. The left femoral artery was cannulated and connected to a pressure transducer (Statham Instruments, Oxnard, Calif.). The mean arterial blood pressure was continuously recorded on a polygraph (Grass Instruments Co, Quincy, Mass).

The perfusion system started and ended in two separate chambers of an electromagnetic balance. The total weight on this balance was continuously registered by a pen-recorder set to deflect $30 \mathrm{~mm}$ when $1 \mathrm{ml}$ of fluid was aspirated from the balance. A non-absorptive marker, ${ }^{14} \mathrm{C}$-polyethylene glycol, was added to the perfusate. The net water transport was calculated from the perfusion rate and the change in concentration of the tracer during its passage through the gall bladder. In the experiments where intra-arterial infusions of noradrenaline (1 $\mu \mathrm{g} / \mathrm{min} / \mathrm{kg}$ body weight) or isoproterenol $(1 \mu \mathrm{g} / \mathrm{min} /$ kg body weight) were given, a plastic catheter was inserted into the splenic artery with its end located in the coeliac artery. In the experiments in which nerve stimulation was studied the splanchnic nerves were bilaterally divided at the preganglionic level. The distal ends of the nerves were placed on silver ring electrodes. Square wave stimuli were delivered by a Grass stimulator (Model S 5) and the nerves were stimulated at $8 \mathrm{~V}, 2 \mathrm{~ms}$, and $8 \mathrm{~Hz}$. The adrenal glands in these experiments were excluded from blood circulation by ligatures.

\section{ESTIMATION OF CHANGES IN GALL BLADDER VOLUME}

Rapid displacements of fluid from or to the gall bladder lumen are detected as fast changes in weight on the balance.

RECORDING OF HEPATIC BILE FLOW

In all experiments the common bile duct was cannulated at its insertion in the duodenal wall and connected to an optical drop-recorder operating a pen-recorder.

\section{DRUGS AND SOLUTIONS}

The gall bladder was perfused by an electrolyte solution $\left(\mathrm{Na}^{+} 130, \mathrm{~K}^{+} 5, \mathrm{Cl}^{-} 105, \mathrm{HCO}_{3}{ }^{-} 30\right.$ $\mathrm{mmol} / \mathrm{l})$ buffered to iso-osmolarity $(310 \mathrm{mmosm} / 1)$ with mannitol. Noradrenaline and isoproterenol (Isoprenalin) were purchased from Apoteksbolaget, Sweden, and atropine from ACO, Sweden. Phentolamine (Regitine, CIBA) was used as an adrenergic $\alpha$-blocking agent.

\section{STATISTICS}

The calculations were performed by analysis of variance (Tukey's method for multiple comparison), pairing design test, and Wilcoxon's signed rank test.

\section{Results}

NORADRENALINE

In seven cat experiments noradrenaline $3.0 \times 10^{-6}$ $\mathrm{mmol} / \mathrm{h} / \mathrm{kg}$ body weight $(1 \mu \mathrm{g} / \mathrm{min} / \mathrm{kg})$ was intraarterially infused into the coeliac artery during 60-90 minutes. The arterial blood pressure increased $21 \pm 3 \mathrm{~mm} \mathrm{Hg}$ in response to this dose of the drug. In all the animals the rate of net water absorption was raised. The average response (Table 1) was an increase of $72 \%$. No significant change in gall bladder volume in response to noradrenaline was recorded in eight animals (Table 2). The outflow of hepatic bile, however, was reduced during the infusion of noradrenaline (Table 3 ).

In another group of five animals noradrenaline was infused after pretreatment with phentolamine (2-4 mg), an $\alpha$-adrenergic blocking agent. In these animals no significant change in the arterial blood pressure was seen in response to noradrenaline. Nor were the net water absorption (Table 1) hepatic bile outflow (Table 3 ), or gall bladder volume changed by the noradrenaline (Table 4 ).

\section{ISOPROTERENOL}

In eight cat experiments isoproterenol $1.8 \times 10^{-6}$ $\mathrm{mmol} / \mathrm{h} / \mathrm{kg}$ body weight $(1 \mu \mathrm{g} / \mathrm{min} / \mathrm{kg}$ body weight $)$

Table 1 Average response ( $\pm S E$ ) in net water transport to adrenergic agonists

\begin{tabular}{|c|c|c|c|}
\hline & \multicolumn{3}{|c|}{ Net water absorption $(\mathrm{ml} / \mathrm{h})$} \\
\hline & Rest & Infusion & $\begin{array}{l}\text { After } \\
\text { infusion }\end{array}$ \\
\hline $\begin{array}{l}\text { Noradrenaline }(n=7) \\
\text { Noradrenaline after } \\
\text { blocking with } \\
\text { phentolamine }(n=5)\end{array}$ & $0 \cdot 60 \pm 0.07$ & $1.03 \pm 0.13^{*}$ & $0.94 \pm 0 \cdot 16$ \\
\hline Isoproterenol $(n=5)$ & $0 \cdot 72 \pm 0 \cdot 23$ & $0 \cdot 76 \pm 0 \cdot 23$ & $0.71 \pm 0 \cdot 24$ \\
\hline
\end{tabular}

${ }^{*} \mathrm{p}<0.005$. 
Table 2 Average response $( \pm S E$ ) in gall bladder volume in response to adrenergic agonists and splanchnic nerve stimulation

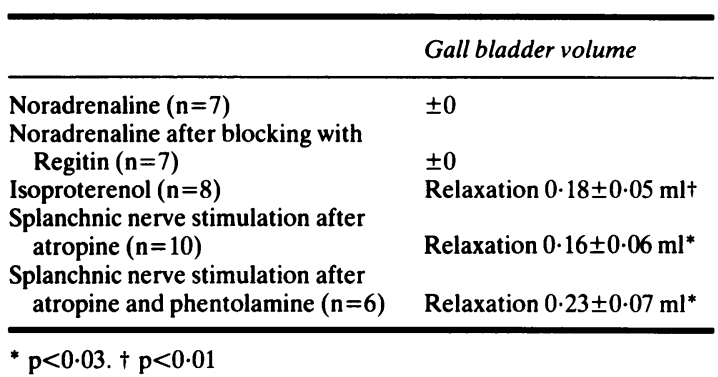

was intra-arterially infused into the coeliac artery. The average response can be seen in Tables 1,2 , and 4. The gall bladder net water absorption rate was not significantly changed but according to the volume registrations a gall bladder dilatation that averaged $0 \cdot 18 \pm 0.05 \mathrm{SE} \mathrm{ml}$ was seen. The hepatic bile outflow from the common bile duct was not significantly changed in response to isoproterenol.

\section{ELECTRICAL STIMULATION OF SPLANCHNIC} NERVES

In 10 atropinised $(1 \mathrm{mg} / \mathrm{kg}$ body weight $)$ cats the splanchnic nerves were bilaterally stimulated $(8 \mathrm{~V}, 2$ $\mathrm{ms}, 8 \mathrm{~Hz}$ ). A representative experiment is demonstrated in the Figure. The splanchnic stimulation raised the arterial blood pressure, caused an initial relaxation of the gall bladder, reduced the outflow of hepatic bile and significantly increased the rate of net water absorption. The

Table 3 Average response ( $\pm S E$ ) in bile overflow from liver to adrenergic agonists and sympathetic nerve fibre activation

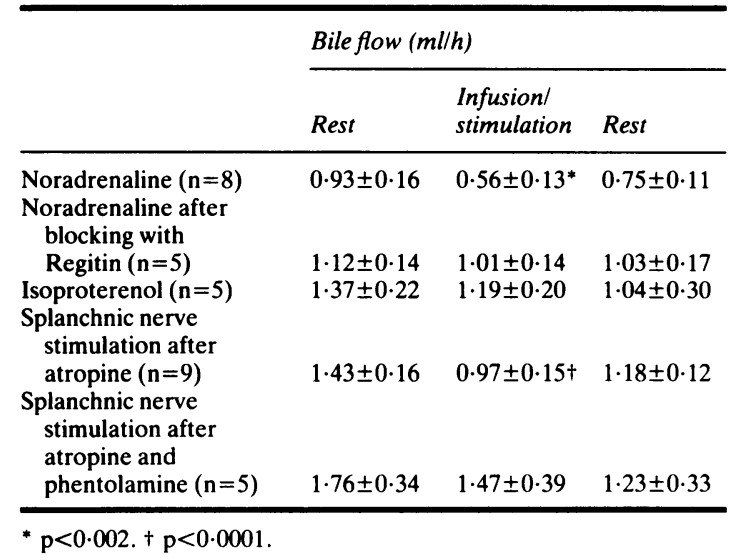

Table 4 Average response ( $\pm S E$ ) in net water transport to sympathetic nerve fibre activation after atropine

\begin{tabular}{llll}
\hline & \multicolumn{2}{l}{ Net water absorption $(\mathrm{ml} / \mathrm{h})$} \\
\cline { 2 - 4 } & Rest & Stimulation & $\begin{array}{l}\text { After } \\
\text { stimulation }\end{array}$ \\
\hline $\begin{array}{c}\text { Splanchnic nerve } \\
\text { stimulation after } \\
\text { atropine ( } \mathrm{n}=10)\end{array}$ & $0.60 \pm 0.13$ & $0.82 \pm 0 \cdot 14^{*}$ & $0.63 \pm 0.12$ \\
$\begin{array}{c}\text { Splanchnic nerve } \\
\text { stimulation after } \\
\text { atropine and } \\
\text { phentolamine ( } \mathrm{n}=5)\end{array}$ & $0.64 \pm 0.29$ & $0.61 \pm 0.30$ & $0.60 \pm 0.26$ \\
\hline${ }^{*} \mathrm{p}<0.002$. & & & \\
\hline
\end{tabular}

average responses in 10 animals are demonstrated in Tables 2, 3, and 4 .

Activation of the splanchnic nerve fibres in five atropinised animals after phentolamine did not significantly change the arterial blood pressure, net water transport in the gall bladder, nor hepatic bile outflow (Tables 2 and 4 ). In this situation, however, the gall bladder significantly relaxed (Table 2).

\section{Discussion}

The effect of adrenergic drugs and electrical stimulation of the splanchnic nerves on gall bladder function were studied by a perfusion technique in anaesthetised cats. It was found that noradrenaline and electrical stimulation of the splanchnic nerves significantly increased the rate of net water absorption in the gall bladder. The findings that isoproterenol, an adrenergic $\beta$-receptor stimulating drug, did not influence the absorptive function of the gall bladder and that the effect of noradrenaline was completely blocked by phentolamine, an $\alpha$ receptor blocking agent, demonstrate that the increase in net water absorption rate is induced by a stimulation of $\alpha$-adrenergic receptors. The finding that isoproterenol relaxes the gall bladder supports the earlier findings by Persson ${ }^{15}$ that the adrenergic relaxation of the gall bladder is mediated by $\beta$-receptors. The effects on the bile outflow from the common bile duct are difficult to evaluate. Noradrenaline and electrical stimulation of the splanchnic nerves reduce the bile outflow. This can be explained by a reduced bile secretion by the liver and the bile ducts but also by a relaxation of the bile ducts.

The present results should be contrasted with the findings by Diamond ${ }^{2}$ that adrenaline has a slight inhibitory effect on net water transport on the fish gall bladder in vitro. Onstad, ${ }^{6}$ on the other hand, found that noradrenaline increased absorption by 
ARTERIAL BLOOD PRESSURE, $\mathrm{mm} \mathrm{Hg}$
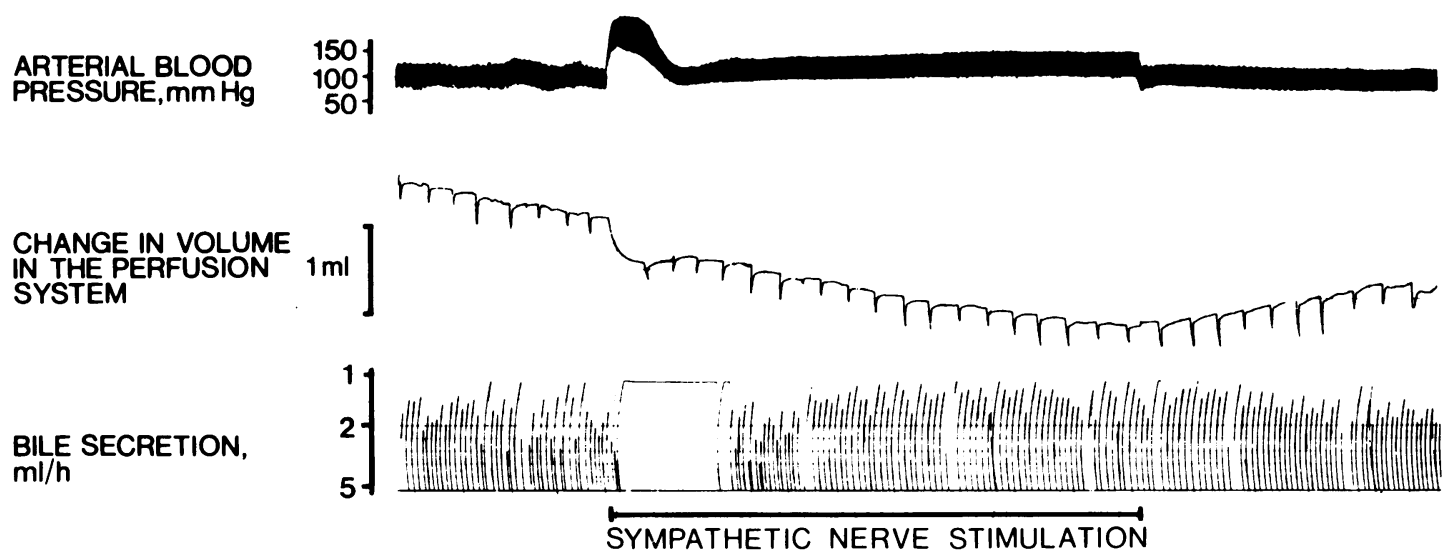

NET WATER ABSORPTION, PEG-METHOD, $\mathrm{ml} / \mathrm{h}$
$-0.82$
$-1.49$
$-0.82$

TIME,min

60

Figure Representative experiment in which the splanchnic nerves are bilaterally stimulated in an atropinised animal and the adrenal glands are excluded from circulation. Note the rise in arterial blood pressure, the relaxation of the gall bladder, the reduced outflow of hepatic bile and increased gall bladder net water absorption in response to the nerve stimulation. The net water absorption rate is calculated from the change in PEG concentration in the perfusate when passing through the gall bladder. The outflow of hepatic bile is registered by a drop recorder unit: one vertical line on the curve denotes one drop.

the human gall bladder in vitro. Species differences and differences in experimental approach may explain the discrepancy. The mucosal cells of the gall bladder, in vivo in the presence of blood circulation, blood-born factors, and autonomic nerves in the present study increased the net water absorption rate in response to $\alpha$-adrenergic stimulation.

The findings can be compared with the effects of adrenergic drugs and electrical stimulation of the splanchnic nerves on the net water transport in the small intestine. Field and $\mathrm{McColl}^{7}$ and $\mathrm{Hubel}^{8}$ demonstrated in vitro and in vivo, respectively, that noradrenaline increased net water uptake, probably via an effect on the net uptake of $\mathrm{Na}$ and $\mathrm{Cl}$. It has been suggested by Kreis and Fordtran ${ }^{16}$ that $\alpha$ adrenergic stimulation in the small intestine enhances active sodium and chloride absorption by an increase in mucosal cell cGMP. In the in vitro gall bladder it has been demonstrated that an increase of intracellular cAMP will reduce the fluxes of sodium and chloride into the mucosal cells. ${ }^{17}$ An increased net water absorption in the gall bladder can well be explained by reduction of cAMP and increase of cGMP in the mucosal cells induced by a direct $\alpha$-receptor stimulation.

The precise site of action of the sympathetic nerves on net water uptake in the gall bladder is not known. The distribution of the adrenergic fibres in the gall bladder wall has been studied by several groups. Baumgarten and Lange ${ }^{11}$ described a direct and indirect noradrenergic system of nerves to the smooth muscle in the gall bladder. The nerves in the direct system primarily end in blood vessels and smooth muscle cells and the nerves in the indirect system were supposed to act on intrinsic excitory neurons. They also found a higher content of noradrenaline in the neck of the gall bladder than in corpus and fundus. Kyösola and Penttilä ${ }^{10}$ in the human gall bladder found a sparse noradrenergic innervation of the mucosa and dense innervation of the fibromuscularis.

Besides a direct effect on the muscosal cells, an effect demonstrated to be possible by the in vitro findings by Onstad, ${ }^{6}$ sympathetic nerves may, via a ganglionic site of action, inhibit release of a neurotransmitter which inhibits water uptake. A possibly postganglionic transmitter is acetylcholine but this is ruled out in the recent experiments, as the animals were atropinised. It has recently been postulated that VIP is a neurotransmitter in the gastrointestinal tract. ${ }^{18}$ VIP is known to reduce net fluid absorption and even produce a net secretion into the lumen of the gall bladder ${ }^{4}$ and the release of this peptide from the gastrointestinal tract is decreased upon stimulation of the splanchnic 
nerve. ${ }^{19}$ The VIP concentration is then reduced both in portal and arterial blood. The $\alpha$-adrenergic effect in the present study could be either an inhibition of VIP-release from other organs in the gastrointestinal tract or an inhibition of VIP-release locally in the gall bladder wall. Nerve fibres immunoreactive to VIP have been demonstrated just beneath the epithelium, and nerve cell bodies immunoreactive to VIP are shown in the submucosa of the gall bladder in several species including cat and man. ${ }^{20} \mathrm{~A}$ possible mechanism is thus an $\alpha$-adrenergic ganglionic inhibition of VIP-release by neurons in the gall bladder mucosa.

The increased net water transport in the gall bladder might be explained not only by an enhanced 'lumen to blood' flux but also by a reduced 'blood to lumen' flux of sodium, chloride, and water. A possible explanation could be an inhibition of secretory glands in the gall bladder but adrenaline has been shown to have no effect on the glycoprotein secretion in the mouse gall bladder. ${ }^{21}$

Whatever the mechanism that is involved it is of interest to note that adrenergic nerves and circulating catecholamines can increase the net water absorption from the gall bladder lumen and thereby enhance its concentrating function. There are reasons to believe that with increased adrenergic activity, the sphincter of Oddi contracts, ${ }^{15}$ the gall bladder relaxes, and the organic contents of the gall bladder are more rapidly concentrated.

This research has been sponsored by grants from the University of Göteborg, The Göteborg Medical Society, and the Swedish Medical Research Council (17X-04984). Miss Monica Wallin is gratefully acknowledged for skilful technical assistance.

\section{References}

1 Johnston CG, Ravdin IS, Austin JH et al. Studies of gallbladder function. V. The absorption of calcium from the bile free gallbladder. Am J Physiol 1932; 99: 648-55.

2 Diamond JM. Transport mechanism in the gallbladder. In: Handbook of Physiology. Sect 6 vol 5. American Physiological Society 1968, 2451-82.

3 Jansson R, Svanvik J. Effects of intravenous secretion and cholecystokinin on gallbladder net water absorption and motility in the cat. Gastroenterology 1977; 72: 639-43.

4 Jansson R, Steen G, Svanvik J. Effects of intravenous vasoactive intestinal peptide (VIP) on gallbladder function in the cat. Gastroenterology 1978; 75: 47-50.
5 Westphal K, Gleichmann F, Soika G. Thier experimentelle Beobachtungen uber nervös bedingte Resorbtionsschwankungen der Gellenblase mit teilweisser Beruchtsichtigung des Lebergallenflusses. Arch Ges Physiol 1931; 227: 204-19.

6 Onstad GR, Schoenfield LJ, Higgins JA. Fluid transfer in the everted human gallbladder. J Clin Invest 1967; 46: 606-14.

7 Field M, McColl I. Ion transport in rabbit ileal mucosa. Effects of catecholamines. Am J Physiol 1973; 225: 852-7.

8 Hubel KA. Intestinal ion transport: Effects of norepinephrine, polycarpin and atropine. Am J Physiol 1976; 231: 252-7.

9 Brunsson I, Eklund S, Jodal $M$ et al. The effect of vasodilatation and sympathetic nerve activation on net water absorption in the cat small intestine. Acta Physiol Scand 1979; 106: 61-8.

10 Kyösola K, Penttilä O. Adrenergic innervation of the human gallbladder. Histochemistry 1977; 54: 209-18.

11 Baumgarten HG, Lange W. Extrinsic adrenergic innervation of the extrahepatic biliary duct system in guinea pigs, cats and rhesus monkeys. Z Zellforsch 1969; 100: 606-15.

12 Lundberg JM, Hökfelt T, Nilsson G et al. Peptide neurons in the vagus, splanchnic and sciatic nerves. Acta Physiol Scand 1978; 104: 499-501.

13 Björck S, Jansson R, Svanvik J. The influence of adrenergic drugs and electrical stimulation of the splanchnic nerves on the concentrating function of the gallbladder. Gastroenterology 1979; 76: 1101.

14 Svanvik J, Jansson R. An experimantal method for studying in vivo gallbladder absorption. Gastroenterology 1977; 72: 634-8.

15 Persson CGA. Dual effects on the sphincter of Oddi and gallbladder induced by stimulation of the right great splanchnic nerve. Acta Physiol Scand 1973; 87: 334-43.

16 Kreis GJ, Fordtran JS. Physiology and pathophysiology of ion and water movement in the human intestine. In: Sleisenger MH, Fordtran JS, eds. Gastrointestinal disease. Philadelphia: Saunders, 1978: 297-313.

17 Frizzell AR, DuGass MC, Schultz SG. Sodium chloride transport by rabbit gallbladder, direct evidence for a coupled $\mathrm{NaCl}$ influx process. J Gen Physiol 1975; 65: 769-95.

18 Fahrenkrug J, Gallbo H, Holzt $\mathrm{J}$ et al. Influence of the autonomic nervous system on the release of vasoactive intestinal polypeptide from the porcine gastrointestinal tract. J Physiol (Lond) 1978; 180: 405-522.

19 Fahrenkrug J, Haglund U, Jodal M et al. Nervous release of vasoactive intestinal polypeptide in the gastrointestinal tract of cats: possible physiological implications. J Physiol (Lond) 1978; 284: 291-305.

20 Sundler $\mathrm{F}$, Alumets J, Håkansson $\mathrm{R}$ et al. VIP innervation of the gallbladder. Gastroenterology 1977; 72: 1375-7.

21 Axelsson, $\AA$, Danielsson $\AA$, Henriksson $\mathrm{R}$ et al. Secretory behaviour and ultrastructural changes in changes in mouse gallbladder principal cells after stimulation with cholinergic and adrenergic drugs. Gastroenterology 1978; 76: 335-40. 